\title{
New Policies for Science and Technology and the Impacts on Public Research Institutes: a Case Study in Brazil
}

\author{
Thales Haddad Novaes de Andrade \\ Social Sciences Department, Federal University of São Carlos (UFSCar), Brazil \\ Lucas Rodrigo da Silva \\ Master in Science and Technology Policy, State University of Campinas \\ (Unicamp), Brazil

\section{Leda Gitahy} \\ Science and Technology Policy Department, State University of Campinas \\ (Unicamp), Brazil
}

This article aims to discuss how technological production has been affected by new organizational patterns of funding and evaluation, international transformations in terms of the reorganization of research centers, and changes in innovation practices. Researchers and scientists have had their activities redefined through new organizational formats that today are well-established. The purpose here is to verify the impacts that these tendencies have had on the scientific and technological production of Public Research Institutes. We analyzed the case of the Technological Research Institute (Instituto de Pesquisas Tecnológicas - IPT) and found that from the 1990s onwards, research institutions in Brazil internalized organizational forms that enabled them to place themselves in the international agenda as reputational agents, and that the IPT internalized an international agenda, hiring new services and with new budgets. The institutions of scientific research tended to align their interests with hegemonic devices and to withdraw the participation of agents not able to make explicit the new formulas for recognition in the scientific field.

Keywords: Science and technology policies; public research institutes; Brazil; IPT; researchers 


\section{Introduction}

This paper discusses how technological production has been suffering the effects

1 of international transformations in terms of the institutional reorganization of research centers and changes in the development of funding for innovation practices. Technicians and scientists, who have traditionally been central to technological development, have had their activities redefined through new organizational formats which today are well-established.

The globalization and internationalization of science represent tendencies that have strongly affected the constitution of social groups that lead technological practice in a global context. Today it is possible to detect global processes of connection among companies, laboratories and public research institutions creating science and technology, which are both localized and asymmetrical (Albert and Laberge, 2007; Gingras, 2002; Vessuri, 2008).

The question that now arises for the peripheral countries is: what impact has the internationalization of scientific research had on national institutions? How have national scientific elites been behaving in light of the new parameters of technological research funding?

In this new scenario, the formation of a new kind of science creates an agreement between the research community and market interests. The purpose of this text is to verify the impacts that these tendencies have had on the scientific and technological productivity of the Public Research Institutes. To elucidate these questions, we analyze the case of the Technological Research Institute (Instituto de Pesquisas Tecnológicas - IPT), part of the University of São Paulo (USP) and linked to the Development, Economy, Science and Technology Department of the state of São Paulo.

With this case study, we intend to analyze how innovation policies have interfered in the organizational criteria of the Institute and its scientific production, and where researchers and technicians stand regarding the new innovation policies. From a discussion on organizational logics, the transformations taking place in Public Research Institutions (Instituições Públicas de Pesquisa - IPPs) can be observed over time (Salles-Filho et al., 2000).

Firstly, Science and Technology policy in Brazil will be discussed, as well as its implications for research activities. Then, the text will discuss the Brazilian IPPs, seeking to emphasize the historical changes they have been undergoing and how these imply an adherence to tendencies arising in the international context. Finally, the case of the IPT - an illustrative example of the internationalization of new scientific practices in the IPPs - will be briefly discussed. 


\section{Globalization, Science \& Technology}

Noble's analysis (1988) of technological development in the US shows deep connections between the country's economic system, scientific culture and technological practice. In Noble's opinion, from the beginning of the 20th century, the US began to experience the emergence of a great military-industrial-scientific complex, whose internal coherence gradually solidified. The subsequent spread of this model to other countries and the globalization of Research \& Development (R\&D) led to a major shift in the relationship between science, technology and innovation practices.

Electrical and chemical industries formed the cutting edge of this process as they synergistically interlinked industry and science for the first time in the $20^{\text {th }}$ century. Engineers, especially electrical and chemical ones, became the elite of this technological development as they began to hold highly significant positions in diverse strategic institutions such as universities, technical colleges and scientific organizations, and on the corporate boards of private enterprises.

The holding of these skilled positions meant that a specific sort of knowledge achieved a privileged position in major industrial segments and decisively influenced the areas of corporate governance and planning of university research and undergraduate programs in technological fields, especially engineering.

...engineers with scientific training, taken up by large corporations, merged the demands of monopoly capitalism and modern technology into a formal system. The modern management, which in engineering represented a shift in focus from the natural to the social realm, from the forces of production to social relations, was a deliberate attempt to alleviate the tension between the two, causing both to fit within the limits of monopoly capitalism. (Noble, 1988: 27)

This systematization of activities involving a rational management of business, technical training, professionalization and participation in scientific organizations allowed some branches of engineering to control the structuring of a highly hierarchized and strategic field, reconciling economic, managerial and scientific interests in favor of monopoly capital. Engineering took on a position of undisputed leadership and started to disseminate its scientific values and technological design in different branches of the economy. The behavior of public agencies, enterprises and universities points to a convergence of interests between previously dispersed elites.

A similar process took place in Brazil throughout the $20^{\text {th }}$ century, except engineering was extremely dependent - both politically and in terms of resources - on government departmentalism, which prevented it from getting its values across as fiercely as in the core countries (Kawamura, 1981). 
In the late $19^{\text {th }}$ and early $20^{\text {th }}$ centuries, there was an urgent need to organize large industries according to both administrative and technical skills. For this, it was essential to ensure space for a privileged group of workers with these two characteristics. These groups of professionals were responsible for systematizing and quantifying the operations of important corporate groups, improving accounting methods, estimating expenditures and processing statistical data for various purposes. The hierarchization of functions and intersectoral reporting were also set up by standardizing procedures and by the monopolization of technical expertise and administrative tools under the control of an elite of skilled engineers, who held strategic positions in North American corporations, and who later disseminated their precepts and procedures to corporate and scientific institutions worldwide.

After World War II, the radicalization of these trends and the influence of other agents were noticeable. There was a great increase in the participation by the military and public sectors in funding science and technological innovation. The US government's participation in establishing the technological agenda strengthened the elite group formed within the canons of electrical engineering and led to a connection of once-dispersed sectors, such as biophysics, biochemistry and other neighboring areas (Velho, 2011).

In Latin America, North American institutions were vital for the development of strategic scientific areas. From the beginning of the $20^{\text {th }}$ century, the Rockefeller Foundation enabled staff training in health to take place, interacting intensely with national institutions and sending professionals for training abroad (Faria, 2007). American scientific philanthropy, coupled with the modernizing impulse of our elites in the first decades of the $20^{\text {th }}$ century, is a successful example of international connections that enabled the development of an innovative project for health policy in an underdeveloped nation still aligned to a traditional way of living, institutionally speaking.

Economic globalization, which began mainly in the 1980s, had a dramatic impact on the reconfiguration of these ruling groups in terms of science and technology (Humbert, 2005). Companies that were leaders in certain areas, such as chemical and pharmaceutical industries, began to invest heavily in technology and establish networks beyond national boundaries, sharing expertise and ways of working in different continents. These groups began to articulate in an increasingly synergistic and complementary fashion, establishing a closer dialogue between technology production centers and technology consumers. This differentiation was no longer very clear once producers and consumers began sharing a growing amount of technological expertise due to the reticular behavior of large corporations.

Humbert (2005) points out that there were great changes in the technological and scientific policies of large enterprises, which created an increased presence of relevant activities in companies located in less privileged places. 
Many authors used to emphasize that multinational firms were conveying obsolete or outdated technologies and that it was not a full transference, and that it was generally overpriced. The globalization of technology was contained within a unique context; multinational firms are no longer reluctant to conduct Research \& Development - R\&D - abroad, not only in industrialized countries but also in underdeveloped nations... thanks also to the decentralization allowed by the development of Information Technology - IT. (Humbert, 2005: 275)

In other words, dominant scientific groups present in the core nations began to establish a closer dialogue with the ruling groups of peripheral countries through the dissemination of expertise in technologically integrated laboratories, sharing patents and inputs. The design of products with potential for global reach, the internal disputes at large corporations in bidding processes for the exploitation of technological products, and the growing rates of enrolment in educational institutions in different parts of the world allowed for opportunities to be shared, privileged groups to be trained in diverse centers and for decentralized decision-making. Large transnational firms began to experience what some analysts call technological diversification, a new way of integrating expertise and project development opportunities. According to Gomes's (2003) analysis:

Technological diversification became an important feature in TNCs to the extent that subsidiaries abroad have played specific roles in the functions of R\&D, whether in the continued emphasis on the local process of innovation, or in developing organizational capital that allows them to integrate the technological activities of dispersed units. The increasing geographic dispersion of strategic assets drives the capacity of foreign subsidiaries, both with regard to horizontal growth - of communication across national borders - and in a vertical direction - one of systematic use of the technological expertise of the organization's several bases. Therefore, the object of research has increasingly moved away from the strategic benefits of using the emerging resources of a particular foreign subsidiary towards the advantages associated with continuous integration... IT has enabled subsidiaries to integrate in the central laboratories of the TNCs, providing them with conditions to develop and participate in other technological activities besides the traditional roles of adapting to processes and products" (Gomes, 2003: 268)

The extensive literature on the internationalization of $R \& D$, which points to the existence of several corporate strategies for scientific and technological development in several regions, shows the existence of a set of shared values across all the different influence levels of these sectors. Albert and Laberge (2007) indicate that technology policy makers in Quebec, Canada, follow economy and innovation parameters created in other centers, forging a situation for the international dissemination of technological and scientific perspectives. The local sectors that do not share the assumptions of the Innovation System and do not follow the procedures attached to this design end up being neglected and do not benefit from decent working conditions and employability (See also Gingras, 2002). 
More recently, in Brazil, these trends have meant that it is possible for the State to not intervene decisively in science and technology and to copy models of international institutions that prescribe formulas for the organizational arrangements of scientific practices (Baumgarten, 2008). In other words, these authors indicate that the innovative elites of the public sector are those who best embody the established values of technological thinking on an international scale, arising mainly from the concepts of innovation systems and local production arrangements.

\section{Science and Technology Policies in Brazil}

In the 1950s, 60s and 70s, scientific and technological development was formally on the political agenda for Latin American countries, but this had little real effect in terms of sustaining and consolidating effective national projects. According to Vessuri (2008), modernization was a recurring collective aspiration and a key policymaking idea for several Latin American countries. However, the research community was unable to ensure a self-sustaining growth process.

In the early 1990s, notes Vessuri (2008), growth prospects for research groups in strategic sectors were undermined due to a hesitating private sector and increasing foreign debt. Until the 1970s, the international circulation of researchers had had an impact specifically upon certain fields of knowledge. However, its scope was restricted to certain economic sectors and had not yet extended to a more global coordination. Latin America's academic elites were still very much under the sway of the State apparatus, and science and technology policies displayed corporate behavior, rather than a dynamic and effective ability to set an agenda (Vessuri, 2008).

Several authors have noted that there are still many economic and institutional challenges for producing technology in Latin America today. Thomas (2006) sees a lack of synergy between the technology and productive sectors and an inability to formulate policy agendas for the field, as some aspects prevent the creation of opportunities for fruitful activities.

In recent years, policymakers in Brazil and other Latin American countries have engaged in aims such as tightening intellectual property regulations, building research networks and obtaining public-private sector synergies in the field of technology. In the case of Brazil, these trends have been consolidated over the last few decades through recent developments in science and technology policies and local activities by international groups. Lagging behind the developed economies, Brazil's technology and innovation policymakers have sought to build a new environment for innovative activities.

The "national-development" perspective was a key aspect of the trajectory of the State's S\&T sector from the 1950s and throughout the military period, when the dominant paradigm for a political project was the prospect of Brazil becoming a regional power, with 
the State as the crucial agent for all major scientific and technological projects, since the national bourgeoisie was not seen as an effective partner. S\&T partnerships were primarily intra-state with no significant connection to the local or international private sector (Baumgarten, 2008). Science and technology policy has traditionally been headed by the research community, located in public universities and state research centers. Even today, groups located in key positions in this community make the main decisions for science and technology policies in Brazil. According to Dagnino (2007), the control that the research community exerted over national science and technology policy was very often related to corporative interests aiming to promote the self-preservation of certain groups and disciplines. To a certain extent, this strong presence of the research community in science and technology policymaking inhibited the participation of agents from the productive sectors. This development model was not seen as successful in terms of providing favorable conditions for companies to introduce technological innovation practices, so Brazil's economic and technological elites sought to address the situation by proposing institutional and cultural changes.

More recently, Brazil's scientific output - particularly from its public universities has done better in terms of the impact of its publications worldwide. But growing scientific productivity has not boosted interaction with the productive sector (Matias-Pereira and Kruglianskas, 2005; Cassiolato and Lastres, 2000).

Given the State's fiscal crises from the 1980s onwards and new emerging forms of research funding and international trends in recent decades, Brazil's technology sector has steadily become more autonomous compared to the scientific and academic sectors. During President Lula's first term of office, an Industrial, Technological and Trade policy (PITCE) was introduced, and the Law of Innovation was passed (Law 10973/04). These efforts were necessary, but not sufficient in terms of altering innovation culture in Brazil. Following in the footsteps of developed economies, a broad range of initiatives was required, with a new social deal for technology to include companies that historically had not invested in this field, universities resistant to market practices and the public bureaucracy. A new elite of policymakers has recently emerged in research institutes and development agencies, aiming to assess the science and technology sector and create specific arrangements for its funding and evaluation (Andrade and Moreira Jr., 2009).

One aspect of these changes refers to the need to adopt an innovation agenda, which was not an important part of science and technology policy until the 1990s. Technological innovation activities started with the formulation of integrated policies covering productive sectors, government, and technological research centers. In recent decades, there has been a major redefinition of these institutions in an attempt to internalize such practices in Brazil (Arbix, 2007).

According to Plonsky (2005), since the 1990s, Brazilian society has tried to build a more effective institutional background for innovation policies. The production of The White Book (Livro Branco) by the S\&T Ministry, the formulation of the Industrial, 
Technological and Foreign Trade Policy (PITCE) and the Law of Innovation during Lula's office were important but insufficient efforts to alter the lack of innovation culture in Brazil (See also Baumgarten, 2008). The creation of sector-level research funding (Fundos Setoriais), the formulation of the Law of Innovation and the growing importance of business incubators with the consolidation of technology parks, all point to the tendency to integrate technological innovation experiences and practices (Lemos, 2000). These policies have led to key articulations and higher productivity, but also significant asymmetries across different research areas, more specifically between basic research and leading-edge technology. An analysis by Pacheco (2007) clearly points to this:

In the technological area, setting up sector-level funds was a new way of funding research in different areas by using non-budgetary funds. Although it involved important benefits for different areas, this initiative led to a significant division as it prioritized high-tech sectors and consequently withdrew funding from scientific research as such (Pacheco, 2007: 213).

One of the most salient results of this policy was to make innovation a separate and self-referential subject in relation to scientific development. Based on Baumgarten's analysis, the distinction between science and technology interests is particularly clear when

(...) around $70 \%$ of funds are allocated to technological development, and, given Brazil's current low capacity to demand technology resources, this creates an imbalance since supply far exceeds the level justified by demand (...) (Baumgarten, 2008: 217).

This imbalance points to a situation that is increasingly visible in S\&T policies, namely the trend toward separating these two fields. Several budgetary funds now tend to be allocated to fields that are clearly performing well in technological terms, to the detriment of science education and research.

Another sign of modifications to the concept of technological research and development can be seen in university research funding. Certain universities have recently introduced incentives for students to develop grant-aided projects that explicitly pursue technological innovation. This means that funds for science student grants from Brazil's federal research agency $(\mathrm{CNPq})$ are being overseen by academics using them to develop projects in companies. The criteria of technological feasibility and synergy with business are thus becoming increasingly significant when allocating funds, providing grants or educating qualified staff. Science and technology do coexist, of course, but parameters for technical feasibility and assessment are being set by academic elites clearly attuned to leading-edge technology.

From the 1990s onwards, new innovation-fostering experiences started to call for industries to engage with this agenda. But partnerships must be arranged and 
experiences exchanged across a very diverse range of industries. Relations between business and state-controlled research centers pose complicated systemic problems for policymakers (Veronese, 2006).

Another clear sign of the increasing internationalization of scientific research can be seen in the consolidation of innovation legislation in Brazil. The Law of Technological Innovation (Federal law number 10.973/2004) "provides incentives for innovation and research in science and technology in industry", and creates an environment in which business could be more involved in developing projects. The law suggests more partnerships between business, universities and science and technology institutes in order to lead innovation processes. This law, based on parameters taken from the French experience, states a number of specific aims: creating an environment for partnerships between universities, technological institutes and companies; incentivizing the involvement of science and technology institutions in the innovation process; and fostering innovation within companies. It also enables firms to be more present in the public sphere by sharing public and private infrastructure and human resources to drive technological research. More controversially, it also regulates conditions for researchers at public research institutions to develop technology projects, offering grants for innovation and additional salaries, as well as allowing start-up technology firms. Funds can be directly channeled towards firms developing innovative projects if they can prove reciprocal benefits and results.

These new rules for technological activity may subject the scientific agenda to business imperatives, and the sectors responsible for producing scientific knowledge might not obtain anything in return. All these demands and connections aim to respond to the commercialization of scientific practice now under way internationally, which has been affecting the course of the scientific and technological logic and determining different approaches to these trends (Lamy and Shinn, 2006).

\section{Organizational Trends in Brazilian Public Research Institutes}

This section briefly discusses the historical context since Brazil's first Public Research Institutes (PRIs) were founded in the mid-19th century, showing five main periods or stages.

PRIs were founded in response to social problems and reflected the utilitarian interests of science in human health, agriculture and livestock rearing, and natural resources (Dagnino and Novaes, 2004). In its early period, science had a close alliance with the rural elites and local bureaucracy, supporting an economic model based on exporting commodities. Different types of knowledge were produced for exporting commodities to Europe. PRIs created under this dynamic fostered industrial development but the enhanced technologies were isolated upgrades, since there was no demand for linking technology with 
production. Note that Brazil at the time was still almost entirely dependent on foreign technology in a colonialist context. This period lasted from the second half of the $19^{\text {th }}$ century through to the 1920s, when the agrarian export model was undermined by the crisis, along with the decline of oligarchic power in Brazil, thus opening a second period through to the late 1950s, when core-development shifted to industrialization and research institutes flourished by producing technology for local use. Technological research institutes were given great importance in this period of growing demand from civil engineering and construction, and from other entrepreneurs (Gitahy, 2001: 687). At this point, there were no fully developed connections across scientific institutions; science policies were not connected and subordinated to international capital (Baumgarten, 2008).

The third period, coinciding with the military government from the 1960s until 1985, was the most vigorous in terms of the local technological development that was supposed to take Brazil to a higher level of industrialization (Dagnino and Novaes, 2004). It was also a time of change (at least in rhetoric), in which Science and Technology (S\&T) policy played a more strategic role. One example was the Médici government's first National Development Plan (locally known as I PND), spanning 1972 to 1974, which sought to reduce the need to import technology. Industrial competition came to be seen as not purely a matter of seeking economic growth, but also of keeping up with the technology led by foreign companies (Baumgarten, 2008).

The Geisel government (1975-1979) produced the second National Development Plan (II PND), incorporating guidelines from the previous plan. This time, the rhetoric actually materialized, and the Geisel government's industrial policy emphasized basic electronics for national security and defense (Baumgarten, 2008). In this third period, the PRIs were much more prominent and concatenated, showing a clear relationship between "bureaucracy and techno-science".

The fourth period was characterized by redemocratization in the 1980s, with economic and political liberalization. Relations between research institutes and the State unraveled because the science policies of the 1960s and 70s had been systematically based on the authoritarian State (Baumgarten, 2008). The main point regarding this period is that the local market was opened to foreign capital in the 1980s - the period generally being referred to as the "lost decade". A neoliberal adjustment of the economy coincided with the state being dismantled and a decline in local production. Meanwhile, PRIs became "dysfunctional", since a market open to foreign capital considerably reduced the demands that had traditionally been made of the PRIs.

The fifth and final period in this historical trajectory of PRIs in Brazil spans from 1990 to the present. Having previously served the demands of the economic elites, the new purpose of these institutions was now to serve different actors such as transnational 
enterprises, for instance, while recovering their dynamism and ability to redirect priorities. There was a deep change in the role of the State. Fiscal restrictions prevented the provision of resources for advanced technological research. In this context, partnerships and other mechanisms were necessary to support innovation projects (Salles Filho et al., 2000). The State's fiscal and policymaking capacity was reduced with the onset of the information economy, which prompted PRIs to readapt and affected different aspects, such as partnerships and funding from non-governmental sources. Economic globalization and expanded market opportunities required greater adaptation from PRIs to cope with new competitive conditions in a flexible and highly competitive space.

Given this new situation, PRIs were forced to change tack. They had to diversify their sources for research funding, attract extra-budgetary sources of funds and pursue financial independence, which created a tendency to rebalance public goals and commercial interests. All these requirements pointed to an increasing need to improve management procedures and maximize results. From this point of view, these institutions clearly had to meet demands and redefine their forms of producing science and technology.

\section{Materials and Methods}

We shall now discuss how this process took place in the case of the Technological Research Institute (IPT), thus identifying the ways in which these trends influenced staff relations and career arrangements involved in the production of technology. As we mentioned in the Introduction, the Technological Research Institute is an illustrative example of the internationalization of new scientific practices in the IPPs in Brazil.

This case study was conducted according to the following strategies:

a) Searching for other studies that focused specifically on the IPT. These materials provided good information on the Institute's history and its working conditions over time (Gitahy, 2001; Gusmão, 1991; Mello, 2000; Salles-Filho et al., 2000).

b) Collecting internal publications, such as development plans, books and some press releases. We collected some of these materials by searching the Institute's website, while others were found in the local library to which we had access.

c) Conducting structured interviews with researchers. In these interviews, we focused mainly on their perceptions regarding new working conditions that have been routinized in the Institute over recent years, especially after the Law of Innovation. Interviewing eight researchers was enough to shed some light on these new trends and their perceptions of them. We interviewed a group of senior researchers involved in the IPT's internal union (ASSIPT) who had information on work conditions, and were able to compare the current situation with established practices. 
After collecting these different materials for our case study, we put together a brief history of the Institute over the decades. Then, we analyzed the new trends and their impacts using the perceptions collected in the interviews.

\section{The Technological Research Institute (IPT) in Five Phases}

The Technological Research Institute (IPT/USP) is a public institution pursuing technological research and innovation. Over recent decades, these organizational trends have been the object of research, and they provide an interesting example to discuss the internationalization of scientific knowledge and transformations in technological work. The institutional trajectory of the IPT and the context of economic and social transformation over time prompted us to present the four phases in our research, as described below.

\section{Phase one: laboratory}

In the IPT's first institutional phase - from 1870 through the early 1920s -, it was merely a laboratory attached to the university; a means of responding to the demands of urban progress (Gitahy, 2001). It was initially connected to the Material Resistance Bureau (locally denominated as "GRM") for the sole purpose of quality assurance in industry. In the 1920s, as the demand for technology increased, the GRM was replaced by a new body reflecting society's new paradigms: the Material Testing Laboratory (known as "LEM").

In terms of the professional activity of researchers and specialists, this period involved expanding roles and responsibilities. Full-time research positions were introduced, as well as partnerships with companies for specific activities. Fees were charged for services, and the first more systematic initiatives were taken to foster researcher specialization (Salles-Filho et al., 2000).

\section{Phase two: founding the IPT}

Phase 2 of the IPT's institutional history starts with its configuration as an independent body. In 1934, some months before the University of São Paulo (USP) was founded, the LEM became the Technological Research Institute (IPT). It took the legal form of an "autarchy", with its own assets and premises, based in the city of São Paulo, but retaining ties with the Polytechnic School (USP). There was much more involvement by private companies, which led to new areas of technical activity, such as metrology and chemistry (Salles Filho et al., 2000). In this period, there was major growth in civil engineering and construction, which leveraged many of the projects developed by the IPT in the 1930s and 40 s, and became its benchmark in the following decades. 
Kawamura (1981) shows that the IPT in this period became one of the main institutions boosting the status of professional engineers in Brazil, inasmuch as it routinized technical activities that had previously been dispersed and under-regulated. The IPT intervened between technical knowledge that was still poorly regulated by professional and scientific associations and an industrial system still poorly concatenated and heavily dependent on public funds. Engineers could work at the IPT without a highly skilled professional system, as could engineer-entrepreneurs in need of more consistent academic knowledge.

\section{Phase three: development ideology and the military regime}

The third phase corresponds to the institutional consolidation of the main activities (in this case, the construction industry) and the corresponding crisis in emerging fields, and lasted from the late 1940s until 1970. During this period, there were two particularly significant processes in Brazil: the 1950s, with an economic boom anchored by a development ideology; and the second period with the first National Development Plan (I PND) introduced by the military regime (Baumgarten, 2008).

This historical context is important because it directly affected the IPT. From the 1940s onwards, the Institute expanded its technological capabilities to new areas of activity beyond civil engineering and construction, and responded to the interests of a more vigorous and ideologically defined national bourgeoisie. Major projects such as São Paulo's new subway system and the Imigrantes highway (between the city of São Paulo and the coast) were very important for the Institute during the military regime, and it was closely involved with these public construction projects that helped improve its image.

In the aftermath of the 1973 oil crisis, a stagnant economy and increasing inflation posed considerable problems for public programs. There was a growing demand for alternative technologies, which gave rise to the 1975 ethanol program. The IPT tried to reorient and assimilate these new technological demands and incorporate related values, but this aim failed to materialize in the medium term (Salles Filho et al., 2000).

Both private companies and public institutes were awarded contracts and offered incentives, allowing them to retain previously consolidated paradigms and reducing the need to pursue new science and technology. Even today, this is reflected in the Brazilian industry's scant appetite for agreements involving cooperation and investment in new scientific and technological trajectories.

\section{Phase four: Business corporation}

In 1971, the state government's Science and Technology Program (PROCET) launched a discussion on science and technology entrepreneurship. From this perspective, research institutes would have to upgrade institutional mechanisms used to obtain funds 
and use them flexibly and autonomously. This whole discussion culminated in the legal format of the IPT being altered in 1976, when its name was changed to reflect its new status as a limited liability business corporation (IPT S.A.), which meant it could organize its activities independently and concentrate on obtaining its own funds and resources. Accordingly, the IPT went on to develop relations with the market in a more organized and efficient manner, free from bureaucratic procedures that could hinder procurement of services or contracts, thus streamlining its activity (Salles Filho et al., 2000). Salles Filho (2000) notes that this paradigm shift was not emulated by other PRIs, which gave the IPT great leeway in terms of projects attracting investment capital, as it became a public "company" or "enterprise".

In the 1980s, like most Brazilian PRIs, the IPT went through a period of crisis as Brazil opened its markets to international capital and the simultaneous process of globalization. Many researchers left the IPT as professional prospects waned and competitive salaries in the market became more attractive to them. Research teams that had been consolidating since the 1970s lost several members and their technological vigor diminished (Gusmão, 1991).

From the 1990s onwards, technological knowledge was seen as an important competitive element, and the IPT's science and technology policies enabled it to arrange new partnerships with firms that could not afford their own R\&D department (Salles Filho et al., 2000; Castro, 2009).

\section{Phase five (1990s): new trends}

Baumgarten (2008) notes that in 2000, S\&T policy in Brazil was not immune to internationally prevailing trends towards commoditizing knowledge and privatizing research priorities, a trend that was also present in research carried out at the IPT. In the last quarter of the previous century, the IPT managed R\&D projects for a number of private and public enterprises and charted a new pattern of scientific and technical activity. In this period, the tone was set for the privatization of all economic activity as part of the trend towards globalization, and there were a series of cuts in the IPT's budgets.

In 1995, to name one example of the IPT's technology partnerships with local firms, agreements to expand technological capacity and production processes were made with companies producing basic materials, such as steelmaker National Steel Company (Brazilian) and Brazilian Metals and Mining Company.

The IPT's first partnership agreement under FAPESP's Technological Innovation program was with steelmaker Cia Siderúrgica Nacional... making medium-efficiency electric steel used for making electric motors (...). The IPT developed an alternate process for making ferroniobium for the Cia Brasileira de Metalurgia e Mineração (...) (REVISTA IPT - Research \& Technology, 2009: 69). 
These initiatives demonstrated closer connections between the IPT, development agencies and Brazilian firms, with more effective programs for innovation. During this period, special attention was given to the Institute's relations with the external environment, steering activities and priorities for different sectors. In the mid-1990s, institutional reorganization gave rise to a business-unit structure at the Institute, and the application of a concept central to business management known as "strategic support units" (locally referred to by the acronym AES).

Strategic support units do not pose a new formal structure, but rather a new way of organizing research and services, enabling a more flexible departmentalized structure; incentivizing networked matrix system arrangements, which may consist of researchers from a single unit or from different units (Salles Filho et al., 2000: 266).

Given its concern with financial dependence on the State, the IPT used this support-unit structure to introduce a new approach to market interests and the State, thus gaining more autonomy in terms of funding and financial management (Salles Filho et al., 2000). As a business corporation, the IPT developed mechanisms to optimize internal management and ensure its institutional autonomy. Support units were critical at this point because they enabled the IPT to make strategic alliances with both public and private companies, thus reducing dependence and legitimizing its initiatives.

Therefore, in the 1990s, the Institute diversified into R\&D in new sectors of science beyond civil engineering and construction, including biomedical research on biodegradable plastics and quality control checks for gas stations in the state of São Paulo to ensure compliance with National Petroleum Agency (ANP) requirements.

In the second half of the 1990s, the proportions of budget and non-budget sources of funds were reversed and prospecting more external business became crucial to sustainability (Salles Filho et al., 2000). From 1995 through 1998, non-budgetary sources of funds jumped from $26 \%$ to $50 \%$, while the state-government budget's contribution fell significantly from $74 \%$ to $50 \%$.

Outside projects in the form of contracts and agreements signed by the Institute during the period accounted for a larger share of revenue, reflecting the IPT's post-1995 policy of encouraging new partnerships and funding arrangements (Salles Filho et al., 2000: 273).

Public and private companies signed more contracts with the Institute, making it increasingly dependent on earning revenue on services demanded by external agents. External projects were therefore increasingly specified and detailed, whereas internal projects such as training programs were subject to less interference from higher instances. This 
aspect matched the important role of external sources of funding in this new institutional configuration.

Within this context of institutional shifts and reorganization of technological activities that the Institute underwent throughout the 2000s, the changes in work conditions became an even more relevant issue. This question will be dealt with in the next section.

\section{Conditions and Careers for Technology Researches in the Recent Setting}

In the early 2000s, many authors emphasized that innovation policies could lead to new conditions in technological development. There was a wide range of perspectives that pointed to the fact that the coming of the knowledge society would increase science production across different levels: national, regional and local. Lemos (2000) stated that globalization, linked to new markets and competitive standards, would rebuild technological production. For other authors, like Cassiolato and Lastres (2000), Brazilian policy makers were implementing policies that would enable our science institutions to redefine their positions on an international scale. There was an optimistic perception of our capacity to internalize such tendencies and establish new parameters of technological innovation in the medium-term.

Our case study shows that this picture is not so clear. It is hard to determine whether these conditions for technological work might lead to an improvement in scientific institutions.

Recently, official research funding agencies have enabled academic researchers to be involved in companies and research institutes through specific arrangements or by providing grants. The emergence of this kind of program demands closer relations between university research and the demands of business, based on a new scientific-technical deal that has been made by these different sectors. One of the central issues in this debate is the emergence of technological entrepreneurship. The introduction of the Law of Technological Innovation in 2004 and incentives for development agencies to enable academics to work for companies means that interfacing between research and production is high on the current agenda.

The Sociology of Science has recently discussed the perspective of "antidifferentialism", in which scientific research and economic production in the globalized world have become so intertwined that their frameworks are now inseparable. Lamy and Shinn (2006) have discussed the response from French scientists and specialists when research was placed on a commercial basis by a new Technology Innovation Law. They noted a trend for scientist-entrepreneurs to join scientific practices with market ones in order to 
preserve the specific features of both fields. They describe researcher-entrepreneurs as showing both academic and business behaviors, so researchers and specialists need to adapt their interests to scientific and economic terms.

This discussion is interesting, since it calls into question the "antidifferentialist" thesis, while emphasizing the contingency of scientific behavior. Scientist-entrepreneurs often

(...) alternate [between] an entrepreneurial system and an academic regime. Pointing to the existence of this mode of sequential coordination confirms the possibility of a non-pathological preservation of differences between science and the market (Lamy and Shinn, 2006: 49).

It is not simply a question of showing that specialists and researchers incorporate commercial logic, note these authors. Certain fields are open to business investment so that new practices and interests coexist, taking the form of specific short-term measures, but this does not mean a total acceptance of market rules.

How do these issues present themselves to the IPT at present? It is interesting that specialists and researchers do not have clear positions on the implications of adhering to new forms of relationship between researchers and business. Despite the growing agenda of interpenetration between entrepreneurs and specialists, IPT professionals do not clearly say how they are involved in these forms of technical-scientific practice.

As part of this context in which the IPT started to alter its institutional logic and reorganize technological practices in the 1990s, the issue of researchers' conditions and careers came to the fore. Many researchers left the IPT in the 1990s and staff numbers fell from approximately 3,000 in the 1980s to 1,800 (Mello, 2000). From 1994 to 1998, there was a significant drop of around $14 \%$ in the number of researchers and graduate assistants. This major loss in terms of scientific and technological leadership was not repaired in subsequent years.

From 2000 onwards, this situation became more critical. This diagnosis is clearly shown in the 2002 Master Plan, which notes the situation in which

IPT units and coordinating bodies unanimously agree that the institute requires a policy on renovation and recycling for its workforce. Year after year, the Institute has been losing skilled technical and administrative personnel due to the lack of prospects in terms of salaries and careers, and to the State's contradictory policies. Therefore, the executive board is committed to preserving and renovating its critical mass, as well as readjusting it to the reality of the market (Plano Diretor, 2002: 17).

Inability to tackle market competition is seen as a central aspect of this condition, and the Institute must find ways of attracting staff for technology work. 
One major problem noted by the institution concerns the training and refresher programs for its researchers. The 2002 Master Plan emphasized this aspect as a priority to be addressed:

Firstly, one item appeared in all unit assessments: human resources. Salaries are below levels prevailing in the market, so there is a lack of career prospects within the institution, procedures are slow and it is not hiring, so the IPT has been struggling to retain technical staff at the level of excellence expected by its clients. This leads to concern for the future of the institution, which is heavily dependent on the technical capabilities of its staff. This is perhaps the most critical aspect the IPT is facing (IPT, 2002: 5, emphasis in the original).

As the new century begins, there is a need for new initiatives related to hiring and training through competitive examinations and postgraduate programs to be developed within the Institute. One way of tackling this issue is through programs with graduate students and visiting researchers.

Another problematic aspect for sustainability is that the absence of a skilled marketing sector able to boost the visibility of its services diminishes the Institute's presence for its target segment of small and medium firms (IPT, 2002). According to the researchers interviewed, there are still no regulatory principles for this activity within the Institute. As of yet, there is no data showing use of the technological innovation legislation to bring technology projects into the Institute, and neither have researchers applied for leave of absence to set up firms (Silva, 2009). One of the specialists interviewed said there is still a great sense of insecurity regarding technological entrepreneurship at several research institutions:

In an interview with an ITA (Technological Institute of Aeronautics) professor at a technology park, one of the questions was precisely on the Innovation Law, and he said that the law made him very insecure... he had been invited to work for a company and he wanted to do that, but when discussing this within the ITA, he felt that if he took leave, there might no longer be a place for him when he came back... so he talked about it, but did not feel secure... (Specialist 1$){ }^{1}$

The Law of Technological Innovation is precisely meant to enable these forms of negotiation between research institutions, researchers and companies and to provide regulations for these exchanges. However, a culture has not yet taken root for more agents to be able to adjust their future commitments and predict their modes of scientific work. In other countries, these practices are more deeply rooted and routine, but in Brazil, institutions and researchers do not yet share the same parameters. 
(...) This is because it's a different culture... this support for innovation comes primarily from capitalist countries, the US and Korea.... Take the case of the US, where it is a natural part of academic life; Silicon Valley was nothing more than what they call a spin-off... Researchers automatically go to these companies and it's no wonder that $96 \%$ of patents are generated in the private sector by incorporating this critical mass... In Brazil this [kind of thing] is not seen as being so natural... Until a while ago, if a researcher at the IPT left to do research related to what he was doing here at the IPT, but for a business, this could constitute grounds for dismissal... (Specialist 2).

With the introduction of the Innovation Law, this is no longer a problem, because there is now a legal basis for spin-offs between institutes and companies, with clear rules for both sides. But this issue still has controversial aspects. Researchers still feel insecure about joining in with such new forms of work. If a researcher leaves the Institute temporarily to work on a specific project for a company, there is no alternate assessment within the Institute to recognize this external activity. According to one of the researchers, there is a need for clearer rules regarding external and internal activities:

I allow the researcher to go to such and such a company... but I continue to require things from their unit... either you create a structure that allows you to do this, or it all just amounts to babble (Specialist 2).

This type of statement shows a situation of uncertainty and opposition between the institutional logic and patterns of knowledge transfer. There are still doubts within the Institute regarding whether or not it is feasible for agents to effectively fulfill professional requirements on the one hand, and stay updated in relation to the new rules on innovative activities on the other. These new rules are seen as necessary but at the same time, they change the reputational rules and forms of recognition among scientists and specialists. Alliances with business sectors may finally break down internal accords between researchers, setting new parameters for scientific competitiveness. In the words of one of the researchers concerned with these changing rules, they destabilize the beliefs involved in scientific activity.

The IPT (a PRI) uses açaí fruit to make.... a nano-particle that may be put into cosmetics... is it right for the IPT to be doing this just for Natura?...And if it is now right, should I see this as something likely to happen?... hence this malaise caused by a culture previous to a legal architecture seen as correct, objective, and now acceptable.... so that's it... These basically philosophical issues permeate these laws... when a decision is made that's it... no more. Professional embarrassment in relation to peers... legislation allows this! (Specialist 3). 
The introduction of these new forms of scientific and technological activity connecting institutes with the external environment will redefine practices and rules that can no longer handle more efficient connections. Whitley (2000) notes that scientific institutions that do not prepare their staff for these new forms of collective work will not be able to place themselves in a reputational structure that is more flexible and linked to the hegemonic logic of scientific production. The IPT must build a more flexible normative framework to handle these situations enabled by the Law of Technological Innovation. Further adhesion becomes even more complex in light of the low level of concern among its researchers.

In order to help manage new investments, in July 2008 the IPT set up its Modernization Process Management Cell with the mission of defining more precise strategies for decision-making (REVISTA IPT - Research \& Technology, 2009). The proposal is to make internal processes leaner with more streamlined decision-making.

Researchers show great concern for these practices and major infrastructure investments. Trends toward reformulated rules for research are not being matched by a greater involvement of skilled researchers acting in public institutions. Asked about the direction of these more recent internal rules, another researcher replied:

What I see is that this process of purchasing equipment did not arise from a strategic plan devised by the institution... it was not a plan that involved its staff.... researchers did not contribute their opinions... they just talked about equipment... we could say that this investment was not based on a strategic plan agreed with the Institute's management... (Specialist 3).

According to Whitley (2000), the organizational conditions for researchers to become reputational agents able to set a scientific agenda for the institution have been eroding in recent times. The institutional environment created in this scenario does not create good conditions for employees to take part in these strategic plans. In interviews, researchers point out that new legislation on scientific and technological research and the large investment of funds in recent years has not been accompanied by innovative forms of discussing professional needs or negotiation around shared strategies.

Some work conditions still remain, keeping the researchers apart from the Institute's decision-making process. This organizational expansion of science and technology research and the Institute's participation in broader inter-sector partnerships is not happening concurrently with wider rules for internal dialogue and participation by different actors. Some groups of researchers are still not very aware of these management rules and cannot understand or keep up with technological production taking on more bureaucratic forms. According to Moreira et al. (2007), results provided by this new legal framework regarding innovation are still uncertain. Research institutes, universities and governments 
so far have not created a stable environment in which to implement continuous incentives, especially in the case of the Law of Innovation.

One of the main aspects mentioned in the interviews is that the creation of elaborate institutional management mechanisms has raised the visibility of the more business-like management initiatives. Whether or not these trends are directly affecting conditions for technological work is not so clear. For some researchers, there is still concern about the participation of the different sectors in devising these strategies:

When you create a tremendous structure in the IPT, of infrastructure for nanotechnology, with extremely high capital investment... you're creating what they call an innovation environment... you create an environment that brings in critical mass via competitive procedures for the IPT, and through BNDES investment, you are making...following a predetermined route, so I think that even we, who have been here at the IPT for longer, need to be better informed on this qualitative change that has occurred, if only to better understand what is happening and be able to gauge what we will be doing as a result... this ends up as very simplistic reasoning..."Ah! look... they're just finding money for equipment but not for salaries"... okay, that's what it looks like at first sight...but 150 million's worth of equipment has its own logic, which permeates...the logic of creating an innovation environment, it has a logic... subtract here, add there...So you have to be careful with this, you have to see what this investment has actually brought to the table, this law and this innovation environment, in terms of technology transfer and response to the demands of society... (Specialist 4)

The new reality of internationalized scientific research points to the construction of more sophisticated and flexible managerial frameworks, but also poses problems for the technological conditions of work. The internalization of some new procedures within these organizations still produces tensions that cannot be overcome by management measures. The reputational positions involved in these struggles show that such organizations are still unable to stabilize their options.

These groups tend to redefine their positions, both as professional groups and as reputational agents aiming to rebuild this field. For Whitley (2000), it is combining new management patterns with established status conditions that makes these disputes even harder to coordinate. In this sense, science institutions tend to impose some international conditions that reorganize ancient work practices and organizations worldwide.

In this case, science and technology policies may be conceived not just as an institutional investment, but rather as a specific way of redistributing reputations and skills. Such tendencies are linked to a widespread change in research assessment that has taken place throughout Latin America. The IPT constitutes a good case for observing these new intellectual regimes emanating from international tendencies that are taking over in many emergent countries. 


\section{Final Remarks}

Technological internationalization, the integration of the innovation system, development of technology assessment methodologies and the strengthening of scientific management in the academies and scientific research institutions, along with new forms of financing, all attest to the fact that there is a new social framework for coordinating and managing the network of innovative activities.

The groups that lead science and technology seek to create conditions for a specific framework for technical interests, and constitute an elite on a global scale that has become autonomous in relation to established criteria of legitimacy.

Latin American countries in the 1950s and 60s were not able to keep up with the great scientific and technological boost in the central countries that had been stimulated by the tensions of the Cold War and the space race. At that time, the production of knowledge was more localized and less easily shared, which derailed effective interactions between research centers.

During the globalization era, there occurred an increased circulation of knowledge, and the possibility for greater participation of developing countries in the core of science. However, the neoliberal agenda prevented the allocation of necessary resources, the institutions of scientific research stagnated, and the agenda of different countries could not keep up with the direction of new forms of knowledge production on a worldwide scale.

From the 1990s, research institutions in Brazil internalized certain organizational forms that enabled them to place themselves in the international agenda as reputational agents. The IPT case demonstrates how Brazilian IPPs were encouraged by an international agenda to modify their operational logic, incorporating new hiring services and forms of fundraising.

The parameters of S\&T budget and evaluation set by international organizations are giving rise to new performance patterns for scientific organizations. Institutions of scientific research have aligned their interests with hegemonic devices and withdrawn the participation of agents not able to make explicit the new formulas for recognition of the scientific field.

This paper defends the need for social scientists to work within the perspective of understanding scientific change as the result of political connections that are beyond the traditional spaces of research practice, and that operate complex networks of institutions and agents that have become increasingly significant and impermeable.

Revised by Priscila Moura

Submitted in April 2012

Accepted in July 2013 


\section{References}

AGÊNCIA BRASILEIRA DE DESENVOLVIMENTO INDUSTRIAL. (2004), Política Industrial, Tecnológica e de Comércio Exterior - PITCE. < http://www.abdi.com.br/Paginas/politica industrial.aspx $>$.

ALBERT, Mauthieu and LABERGE, Suzanne. (2007), The Legitimation and Dissemination Processes of the Innovation System Approach - The Case of the Canadian and Québec Science and Technology Policy. Science, Technology, \& Human Values, vo. 32, n 2, pp. 221-249.

ANDRADE, Thales Novaes de. (2005), Inovação e Ciências Sociais: em busca de novos referenciais. Revista Brasileira de Ciências Sociais, vol. 20, n 58, pp. 65-76.

ANDRADE, Thales Novaes de and MOREIRA Jr., Airton. (2009), Aperfeiçoamento gerencial e inovação tecnológica. Sociologias, ano 11, n 22, pp. 198-230.

ARBIX, Glauco. (2007), Inovar ou inovar: a indústria brasileira entre o passado e o futuro, São Paulo: Editora Papagaio.

BAUMGARTEN, Maira. (2008), Conhecimento e sustentabilidade: políticas da ciência, tecnologia e inovação no Brasil contemporâneo. Porto Alegre: Editora da UFRGS/ Editora Sulina.

BRESSER PEREIRA, Luis Carlos. (1998), Reforma do Estado para a cidadania: a reforma gerencial brasileira na perspectiva internacional, São Paulo: Editora 34.

CASSIOLATO, José Eduardo and LASTRES, Helena Maria M. (2000), Sistemas de Inovação: Políticas e Perspectivas. Parcerias estratégicas, $\mathrm{n}^{\mathrm{0}}$ 8, pp. 237-255.

CASTRO, Antonio. (2009), Sobre a história do IPT. http://www.ipt.br/institucional/organizacao/ historico/100/, accessed on 24/04/2009.

CAVALHEIRO, Esper. (2007), A nova convergência da ciência e da tecnologia. Novos Estudos Cebrap, no 78 , pp. 23-30.

CHÉRCOLES, Diego M.; ESCOLAR, Belém M.; MENDIZÁBAL, Guillermo A.; GONZÁLEZ, Francisco J. (2005), Condicionantes políticos y problemas metodológicos en la evaluación de impacto social de las políticas de I+D e innovación. Revista iberoamericana de ciencia, tecnología y sociedad, vol. 2, no 4, pp. 173-200.

DAGNINO, Renato. (2007), Ciência e tecnologia no Brasil: o processo decisório e a comunidade de pesquisa. Campinas: Editora UNICAMP.

DAGNINO, Renato and NOVAES, Henrique. (2004), A adequação sócio-técnica como insumo para a recuperação dos Institutos de Pesquisa. Revista Brasileira de Gestão e Desenvolvimento Regional, vol. 1, n 3, pp. 30-43.

DAVYT, Amilcar and VELHO, Lea. (2000), A avaliação da ciência e a revisão por pares: passado e presente. Como será o futuro? História, Ciências, Saúde-Manguinhos, vol. 7, n 1, pp. 93-116.

FARIA, Lina. (2007), Saúde e política - a Fundação Rockfeller e seus parceiros em São Paulo. Rio de Janeiro: Fiocruz. 
FREEMAN, Christopher. (1975), La teoría económica de la innovación industrial. Madrid: Penguin Alianza.

GINGRAS, Yves. (2002), Les formes spécifiques de l'internationalité du champ scientifique. Actes de la recherche en sciences sociales, vol. 141, pp. 31-45.

GITAHY, Maria Lucia. (2001), Adaptando e inovando: o Laboratório de Ensaios de Materiais da Escola Politécnica e a tecnologia do concreto em São Paulo. História, Ciências, Saúde Manguinhos, vol. 7, n 3, pp. 675-690.

GOMES, Rogério. (2003), O papel das subsidiárias e a internacionalização das atividades tecnológicas pelas empresas transnacionais (ETNs). Gestão e Produção, v.10, nº 3, pp.267-281.

GUSMÃO, Maria Regina P. (1991), Modelo institucional, estrutura de financiamento e demanda tecnológica: a experiência do IPT nos anos 80. (Master Dissertation, UNICAMP.

HUMBERT, Marc. (2005), Globalização e glocalização: problemas para países em desenvolvimento e implicações para políticas supranacionais, nacionais e subnacionais. In: Conhecimento, sistemas de inovação e desenvolvimento, edited by Helena M. M. Lastres, José E. Cassiolato and Ana Arroio. Rio de Janeiro: Editora UFRJ.

INSTITUTO DE PESQUISA TECNOLÓGICO. (2009), Estatuto, São Paulo: IPT.

INSTITUTO DE PESQUISA TECNOLÓGICO DO ESTADO DE SÃO PAULO. (1979), Na era da tecnologia, 80 anos de IPT. São Paulo: Editora IPT.

INSTITUTO DE PESQUISA TECNOLÓGICO DO ESTADO DE SÃO PAULO. (1999), IPT 100 anos de tecnologia. São Paulo: Editora IPT.

INSTITUTO DE PESQUISA TECNOLÓGICO DO ESTADO DE SÃO PAULO. (2002), Plano diretor, São Paulo: IPT.

INSTITUTO DE PESQUISA TECNOLÓGICO DO ESTADO DE SÃO PAULO. (2009), IPT -110 anos: Os desafios e as vitórias em mais de um século dedicado à inovação. Revista do IPT Pesquisa \& Desenvolvimento, vol. 1, pp. 4-96.

KAWAMURA, Lilia. (1981), Engenheiro: trabalho e ideologia, São Paulo: Ática.

LAMY, Ewan and SHINN, Terry. (2006), Lautonomie scientifique face à la mercantilisation Formes d'engagement entrepreneurial des chercheurs en France. Actes de la Recherche en Sciences Sociales, vol. 4, no 164, pp. 23-50.

LEMOS, Cristina. (2000), Inovação na era do conhecimento. Parcerias Estratégicas, vol. 5, no 8 , p.157-179.

MATIAS-PEREIRA, José and KRUGLIANSKAS, Isak. (2005), Gestão tecnológica: a Lei de Inovação Tecnológica como ferramenta de apoio às políticas industrial e tecnológica do Brasil. RAE eletrônica, São Paulo, vol. 4, $\mathrm{n}^{\circ} 2$.

MELLO, Debora. (2000), Um estudo sobre a reorganização institucional no IPT. XXI Paper presented at XXI Simposium on Management of Technology Innovation, , november, São Paulo, SP.

MINISTÉRIO DA CIÊNCIA E TECNOLOGIA. (2002), Livro Branco - Ciência, Tecnologia e Inovação, < http://www.cgee.org.br/arquivos/livro_branco_cti.pdf > 
MOREIRA, Natali Valani; ALMEIDA, Francisco Alberto; COTA, Marcelo Foresti; SBRAGIA, Roberto. (2007), A inovação tecnológica no Brasil: os avanços no marco regulatório e a gestão dos fundos setoriais. Revista de Gestão USP, São Paulo, vol. 14, nº especial, pp. 31-44 .

NOBLE, David. (1988), El diseño de Estados Unidos: La ciencia, la tecnologia y la aparición del capitalismo monopolístico, Madrid, Ministerio del Trabajo y Seguridad Social.

PACHECO, Carlos. (2007), Estratégia para fundos setoriais. Revista Brasileira de Inovação, vol. 6, nº 1, pp. 191-223.

PLONSKY, Guilherme Ary. (2005), Bases para um Movimento pela inovação tecnológica no Brasil. São Paulo em Perspectiva, vol. 19, n 1, pp. 25-33.

SALLES-FILHO, Sergio et al. (ed.). (2000), Ciência, Tecnologia e Inovação: a reorganização da pesquisa pública no Brasil, Campinas: Komedi.

SHINN, Terry and RAGOUET, Pascal. (2008), Por uma sociología transversalista da ciencia, São Paulo, Editora 34.

SILVA, Lucas Rodrigo. (2009), A perspectiva dos pesquisadores de Instituições Públicas de Pesquisa frente às novas tendências organizacionais: o caso do IPT. (Paper, Federal University of São Carlos.

THOMAS, Hernan. (2007), Dinámicas de innovación y cambio tecnológico en El MERCOSUR. Procesos socio-técnicos de construcción de condición periférica. Paper presented at XXV ALAS Congress, Guadalajara, Mexico.

VELHO, Lea. (2011), Conceitos de Ciência e a Política Científica, Tecnológica e de Inovação. Sociologias, vol. 13, $\mathrm{n}^{\circ}$ 26, pp. 128-153.

VERONESE, Alexandre. (2006), A busca de um novo modelo de gestão para a ciência, tecnologia e inovação na política do MCT (1995-2002). Revista de Administração Pública, vol. 40, nº 1 , pp. 107-125.

VESSURI, Hebe. (2008), O inventamos o erramos: La ciência como idea-fuerza em América Latina, Bernal: Universidad Nacional de Quilmes.

WALKER, Richard. (1993), The hidden dimension of industrialization: an expanding division of labor. Futures, vol. 25, nº 6, pp.673-93.

WHITLEY, Richard. (2000), The intellectual and social organization of the sciences, New York, Oxford University Press.

WIENER, Jonathan B. (2004), The regulation of technology, and the technology of regulation. Technology in Society, vol. 26, pp. 483-500.

\section{Notes}

1 The interviews were recorded in October 2009 with senior professionals of the IPT who contributed to an understanding of the organizational changes at the Institute. 